\title{
Bilateral defence and security cooperation despite disintegration: Does the Brexit process divide the United Kingdom and Germany on Russia?
}

\author{
Jonas J. Driedger* (i) \\ American Institute for Contemporary German Studies, John Hopkins University, Washington DC, United States and \\ European University Institute, Florence, Italy \\ ${ }^{*}$ Corresponding author. Email: Jonas.Driedger@EUI.eu
}

(Received 23 October 2019; revised 11 October 2020; accepted 12 October 2020; first published online 11 November 2020)

\begin{abstract}
With wavering US support and Brexit unfolding, cooperation between Germany, the EU's economic powerhouse, and the United Kingdom, Western Europe's prime military power, becomes crucial for Europe's overall ability to deal with a resurgent Russia. Does institutional and normative disintegration between states, such as the Brexit process, weaken bilateral security cooperation? This article argues that such cooperation persists if both states continue to jointly perceive a third actor as threatening while regarding each other as useful and reliable when it comes to ameliorating this shared threat. The argument is tested on a case of intrinsic theoretical, historical, and political importance: British-German cooperation towards Russia before and after the 2016 Brexit referendum. The article finds, against a wide pessimist consensus to the contrary, that cooperation strengthened during the Brexit process. As the Ukraine crisis had caused converging threat perceptions since 2014, Brexit incentivised both sides to signal ongoing reliability to each other and, consequently, to view each other as more capable allies. The article combines qualitative comparisons and congruence analysis, drawing data from British, German and Russian primary sources in their respective original languages, including foreign and security policy documents as well as interviews with stakeholders involved in policy formation.
\end{abstract}

Keywords: EU Disintegration; Russia; Alliances; Brexit; German Foreign Policy

\section{Introduction}

When does bilateral security and defence cooperation towards third states persist despite of ongoing institutional and normative disintegration, such as Brexit? Plenty of research has shown how institutional and normative links can strengthen such cooperation, ${ }^{1}$ but only little work has been done on the effects of disintegration. ${ }^{2}$ This article conceptualises and operationalises bilateral and multilaterally embedded security and defence cooperation towards third states, develops a generalisable and analytically eclectic framework to assess the causes of persistence

${ }^{1}$ James Sperling and Mark Webber, 'NATO and the Ukraine crisis: Collective securitisation', European Journal of International Security, 2:1 (2017), pp. 19-46; James Sperling and Mark Webber, 'The European Union: Security governance and collective securitisation', West European Politics, 42:2 (2019), pp. 228-60; for a general overview, see Harald Müller, 'Security cooperation', in Walter Carlsnaes, Thomas Risse, and Beth A. Simmons (eds), Handbook of International Relations (London: SAGE Publications, 2012), pp. 607-34.

${ }^{2}$ Douglas Webber, 'How likely is it that the European Union will disintegrate? A critical analysis of competing theoretical perspectives', European Journal of International Relations, 20:2 (2014), pp. 341-65.

( $)$ The Author(s), 2020. Published by Cambridge University Press on behalf of the British International Studies Association. This is an Open Access article, distributed under the terms of the Creative Commons Attribution-NonCommercial-ShareAlike licence (http://creativecommons.org/licenses/by-nc-sa/4.0/), which permits non-commercial re-use, distribution, and reproduction in any medium, provided the same Creative Commons licence is included and the original work is properly cited. The written permission of Cambridge University Press must be obtained for commercial re-use. 
amidst disintegration, and tests it with the case of UK-German cooperation towards Russia amid the Brexit process, which is defined as the 23 June 2016 Brexit referendum and the subsequent processes of anticipating and negotiating Brexit. In doing so, the article tests and confirms the framework. It also sheds light on a political process of significant political and historical importance, while contradicting the prominent views that the Brexit process has negatively affected security cooperation among Europe's major powers. ${ }^{3}$

UK-German cooperation towards Russia amidst Brexit represents a crucial test for the question of when and why bilateral security cooperation towards third states persists despite normative and institutional disintegration. This is for six reasons. First, with Russia, Europe faces a direct military threat, which provides a clear focal point to assess bilateral security cooperation towards third states. When the Ukraine crisis escalated in 2014, Russo-Western security relations had rapidly deteriorated to the point that several influential analysts spoke of a 'New Cold War' between Russia and the West. ${ }^{4}$ Western experts and leaders have since worried that Russia might deliberately attack neighbouring member states of the European Union (EU) and of the North Atlantic Treaty Organization (NATO). ${ }^{5}$

Second, the simultaneous weakening of transatlantic ties heightens the importance of major European states to provide, mobilise, and organise security cooperation towards Russia. The United States has long pivoted attention and resources towards Asia. ${ }^{6}$ After a short refocusing on Europe right after the start of the Ukraine crisis, the election of Donald Trump as US President on 8 November 2016 has provided a powerful reminder that the United States' continued commitment to European security cannot be taken for granted, and that NATO might not anymore be a reliable cornerstone of European military security. ${ }^{7}$

Third, a considerable number of senior experts and practitioners stated that the Brexit process would weaken European security cooperation towards Russia. As this article reaches the opposite conclusion, the Brexit process is well suited to test the theoretical framework and showcase its explanatory purchase. Amid heightened concerns about Europe's ability to fend off Russia without American help, the United Kingdom voted to leave the EU in a referendum on 23 June 2016. Among those arguing that this would further decrease European security and lead to strong divergences between the security policy stances of the United Kingdom and the remaining EU member states were Javier Solana, former NATO Secretary General and former EU High Representative for Common Foreign and Security Policy, as well as Nathalie Tocci, advisor to the current EU High Representative for Foreign and Security Affairs. ${ }^{8}$

Fourth, there are numerous well-established causal mechanisms connecting normative and institutional disintegration with weakening bilateral security cooperation. As this article finds persisting, if not rising cooperation amid Brexit, the candidate cause of such persistence should be strongly present and therefore assessable. As the EU had so far represented a major institutional

\footnotetext{
${ }^{3}$ See further below for detailed references on elite statements warning of Brexit's corrosive effects on security cooperation and an elaboration of the theoretical approaches that provide causal mechanisms for such effects.

${ }^{4}$ Dmitri Trenin, 'Welcome to Cold War II', Foreign Policy blog (4 March 2014), available at: \{https://foreignpolicy.com/ 2014/03/04/welcome-to-cold-war-ii/\} (if not stated otherwise, all online resources were last accessed 19 April 2020); Edward Lucas, The New Cold War: Putin's Threat to Russia and the West (rev. $3^{\text {rd }}$ edn, New York, NY: Palgrave Macmillan, 2014).

${ }^{5}$ Richard Shirreff, War with Russia (London: Coronet, 2016); Stéphanie Pézard et al., European Relations with Russia: Threat Perceptions, Responses, and Strategies in the Wake of the Ukrainian Crisis (Santa Monica, CA and Cambridge, UK: RAND Corporation, 2017).

${ }^{6}$ Nina Silove, 'The pivot before the pivot: U.S. strategy to preserve the power balance in Asia', International Security, 40:4 (2016), pp. 45-88.

${ }^{7}$ During a speech at an event in the context of the EU State of the Union, 10 May 2018 in Florence, Nathalie Tocci, advisor to the current EU High Representative for Foreign and Security Affairs, spoke of a 'growing question mark on American reliability' and a 'long journey' to European strategic autonomy (author's notes).

${ }^{8}$ Speech given by Nathalie Tocci at an event in the context of the EU State of the Union, 10 May 2018; speech by Solana on 26 October 2018 (author's notes), both at the European University Institute in Florence (author's notes).
} 
glue between the two, basic liberal and institutionalist reasoning would expect both sides to feel less and less restrained by the preferences of the other, with their respective policies towards third states more and more diverging. ${ }^{9}$ Constructivist accounts of developing discourses of collective identity and bilateral relations would also predict that the Brexit process has been the outcome of an increasing normative and ideational divide between the United Kingdom and remaining EU member states. ${ }^{10}$ Hostile negotiations of post-Brexit arrangements could further sharpen these divisions. Furthermore, the Brexit process involves intense and time-consuming negotiations and demands a lot of diplomatic and bureaucratic attention that might then be unavailable for sustaining the common Russia policy. ${ }^{11}$ This would entail significant divergencies in the operative goals and strategies that remaining EU members and the United Kingdom employed towards Russia. Funding the minimal consensus in goals and strategies on Russia also seems jeopardised by the Brexit process, as numerous experts, independent institutions, and politicians on both sides have warned that Brexit would be economically harmful to the United Kingdom and the EU. ${ }^{12}$

Fifth, cooperation between the United Kingdom and Germany is the cornerstone of any effective pan-European policy towards Russia and should hence be the focal point of any scholarly assessment thereof. This is for several interrelated reasons. Due to collective action problems and scale effects, effective collective defence in Europe depends on consensus among its major powers - the United Kingdom, France, and Germany. ${ }^{13}$ The departing United Kingdom and France are Western Europe's prime military powers. ${ }^{14}$ While the two continue to extensively cooperate in various regions of the world, UK-German cooperation is arguably more consequential than UK-French cooperation when it comes to Russia. Germany, as the EU's economic powerhouse and 'semi-hegemonic state', has most leverage over other European states to act as the hub of a joint Russia policy. ${ }^{15}$ This also applies to influence within the Franco-German 'tandem' where Germany increasingly emerges as the senior partner. ${ }^{16}$ Lastly, the United Kingdom has long been considered one of Europe's most pro-American states, ${ }^{17}$ and Germany as most pro-Russian, ${ }^{18}$ with an influential Russian analyst calling Germany Russia's 'most

\footnotetext{
${ }^{9}$ Robert O. Keohane, After Hegemony: Cooperation and Discord in the World Political Economy (Princeton, NJ: Princeton University Press, 1984); Andrew Moravcsik, 'Taking preferences seriously: A liberal theory of international politics', International Organization, 51:4 (1997), pp. 513-53.

${ }^{10}$ Anna Michalski and Ludvig Norman, 'Conceptualizing European security cooperation: Competing international political orders and domestic factors', European Journal of International Relations, 22:4 (2016), pp. 749-72.

${ }^{11}$ For an overview of the Brexit negotiations, see: $\{$ https://www.consilium.europa.eu/en/policies/eu-uk-after-referendum/\} 5 August 2019.

${ }^{12}$ Charles P. Ries et al., After Brexit: Alternate Forms of Brexit and their Implications for the United Kingdom, the European Union, and the United States (Santa Monica, CA and Cambridge, UK: RAND Corporation, 2017); 'Disorderly Brexit would be "absolute catastrophe” - EU's Juncker', Reuters (19 December 2018), available at: \{https://www.reuters.com/article/uk-britain-eu-junckeridUSKBN1OI1N3\}; 'Worst-case Brexit more painful than Global Financial Crisis, Bank ...', Reuters (28 November 2018), available at: $\{$ https://www.reuters.com/article/uk-britain-eu-boe-idUSKCN1NX263\}; 'Tory minister urges Theresa May to rule out "absolute disaster" of no-deal Brexit', The Independent (21 January 2019), available at: \{https:/www.independent.co.uk/news/uk/politics/ brexit-no-deal-theresa-may-richard-harrington-conservatives-vote-parliament-commons-a8738131.html\}; 'Brexit: Raab and Barnier meet as EU steps up no-deal warnings', The Guardian (19 July 2018), available at: \{https://www.theguardian.com/politics/2018/jul/19/brexit-raab-and-barnier-to-meet-as-eu-steps-up-no-deal-warnings\}.

${ }^{13}$ For the classic departure for this general argument, see Kenneth N. Waltz, Theory of International Politics (Long Grove, IL: Waveland Press, 1979), pp. 161-93. For the European situation, see Hugo Meijer and Marco Wyss, 'Upside down: Reframing European defence studies', Cooperation and Conflict, 54:3 (2018), pp. 378-406.

${ }^{14}$ Andrew M. Dorman, 'The United Kingdom', in Hugo Meijer and Marco Wyss (eds), The Handbook of European Defence Policies and Armed Forces (Oxford University Press, 2018), pp. 71-86.

${ }^{15}$ Webber, 'How likely is it that the European Union will disintegrate?'.

${ }^{16}$ Ulrich Krotz and Richard Maher, 'Europe's crises and the EU's “Big Three”, West European Politics, 39:5 (2016), pp. 1053-72.

${ }^{17}$ Maxine David, 'Ireland and the United Kingdom', in Maxine David, Jackie Gower, and Hiski Haukkala (eds), National Perspectives on Russia: European Foreign Policy in the Making? (London: Routledge, 2013), pp. 48-66.

${ }^{18}$ Susan Stewart, 'Germany', in David, Gower, and Haukkala (eds), National Perspectives on Russia: European Foreign Policy in the Making?, pp. 13-29.
} 
important European partner' in 2018. ${ }^{19}$ Hence, if the Brexit process indeed caused divergence in bilateral cooperation towards Russia, the UK-German case is the most crucial one and should be affected most, rendering it the prime test case for the framework.

Sixth, there has not yet been a study that has systematically investigated this bilateral security cooperation amidst Brexit. Many have explored the general security and defence implications of Brexit. ${ }^{20}$ There have also been specific studies on Brexit and the security of Europe's exposed Northern and Baltic states. ${ }^{21}$ The common view has been that the Brexit referendum further diminished the security of these states. ${ }^{22}$ Most studies on the security implications of Brexit focused mainly on legal, procedural, and institutional aspects of formal EU institutions in the security and defence sphere, which are not very developed to begin with. ${ }^{23}$ There are studies on recent developments into bilateral security and defence cooperation between France and Germany, ${ }^{24}$ between France and the United Kingdom ${ }^{25}$ and between the United Kingdom and the EU. ${ }^{26}$ Some studies sought to probe into the drivers and nature of the Russia policies of individual EU member states. ${ }^{27}$ However, no study has yet sought to systematically assess whether the Brexit process has led to divergence in the common Russia policy of the United Kingdom and Germany. $^{28}$

To fill this gap, this article offers five contributions. First, it conceptualises and operationalises bilateral security cooperation towards third states, distinguishing three constituent elements:

\footnotetext{
${ }^{19}$ Dmitri Trenin, 'Russia and Germany: From Estranged Partners to Good Neighbors', Carnegie Moscow Center (6 June 2018), available at: \{https://carnegie.ru/2018/06/06/russia-and-germany-from-estranged-partners-to-good-neighbors-pub$76540\}$.

${ }^{20}$ Richard G. Whitman, 'The UK and EU foreign, security and defence policy after Brexit: Integrated, associated or detached?', National Institute Economic Review, 238:1 (2016), pp. 43-50; Tim Oliver and Michael John Williams, 'Special relationships in flux: Brexit and the future of the US-EU and US-UK relationships', International Affairs, 92:3 (2016), pp. 547-67; James Black et al., Defence and Security after Brexit: Understanding the Possible Implications of the UK's Decision to Leave the EU - Compendium Report (Santa Monica, CA and Cambridge, UK: RAND Corporation, 2017); Benjamin Martill and Monika Sus, 'Post-Brexit EU/UK security cooperation: NATO, CSDP+, or "French connection"?', The British Journal of Politics and International Relations, 20:4 (2018), pp. 846-63; Rob Johnson and Janne Haaland Matlary, The United Kingdom's Defence after Brexit: Britain's Alliances, Coalitions, and Partnerships (Basingstoke: Palgrave Macmillan, 2019); Cornelia-Adriana Baciu and John Doyle (eds), Peace, Security and Defence Cooperation in post-Brexit Europe: Risks and Opportunities (Basel: Springer International Publishing, 2019).

${ }^{21}$ Eoin Micheál McNamara, 'Between Trump's America and Putin's Russia: Nordic-Baltic security relations amid transatlantic drift', Irish Studies in International Affairs, 28 (2017), pp. 73-98; James Dennison, Ieva Grumbinaite, and Tim Oliver, 'Baltic member states: Estonia, Latvia and Lithuania', in Tim Oliver (ed.), Europe's Brexit: EU Perspectives on Britain's Vote to Leave (Newcastle: Agenda Publishing, 2018), pp. 193-203.

${ }^{22}$ Black et al., Defence and Security after Brexit; Valentin Naumescu and Agnes Nicolescu, 'The impact of Brexit on Central and Eastern European security', Romanian Journal of European Affairs, 18:1 (2018), pp. 97-8.

${ }^{23}$ Whitman, 'The UK and EU foreign, security and defence policy after Brexit'; Rinna Kaljurand et al., Brexit and Baltic Sea Security (Tallinn, Estonia: International Centre for Defence and Security, 2016); Black et al., Defence and Security after Brexit; Naumescu and Nicolescu, 'The impact of Brexit on Central and Eastern European security'; Nora Vanaga and Toms Rostoks, Deterring Russia in Europe: Defence Strategies for Neighbouring States (London: Routledge, 2018).

${ }^{24}$ Ulrich Krotz and Katharina Wolf, 'Franco-German defence and security cooperation', in Meijer and Wyss (eds), The Handbook of European Defence Policies and Armed Forces, pp. 441-58; M. A. Kukartseva and Pierre-Emmanuel Thomann, 'Франко-германская ось ЕС и России', Politeia, 88:1 (2018), pp. 117-34; Delphine Deschaux-Dutard, 'The French-German military cooperation and the revival of European defence after Brexit: Between reality and political myth', in Baciu and Doyle (eds), Peace, Security and Defence Cooperation in Post-Brexit Europe, pp. 53-77.

${ }^{25}$ Martill and Sus, 'Post-Brexit EU/UK security cooperation'.

${ }^{26}$ Monika Sus and Benjamin Martill, 'Channel trouble? Challenges to UK-EU security collaboration after Brexit', in Baciu and Doyle (eds), Peace, Security and Defence Cooperation in Post-Brexit Europe, pp. 29-49.

${ }^{27}$ David, Gower, and Haukkala (eds), National Perspectives on Russia; Tuomas Forsberg, 'From Ostpolitik to "Frostpolitik"? Merkel, Putin and German foreign policy towards Russia', International Affairs, 92:1 (2016), pp. 21-42; David Cadier, 'Continuity and change in France's policies towards Russia: A milieu goals explanation', International Affairs, 94:6 (2018), pp. 1349-69.

${ }^{28}$ Closest come Frederic Ischebeck-Baum, 'Anglo-German intelligence relations and Brexit', Journal of Intelligence History, 16:2 (2017), pp. 95-9.
} 
common goals, common strategies, and common efforts. Second, it develops a causal framework to assess bilateral security cooperation towards third states in the context of multilateral frameworks and major institutional disintegration. The framework stipulates that such cooperation persists when both states perceive the third state as a formidable threat to their own interests and values and simultaneously view each other as both capable and reliable when it comes to ameliorating this threat. This framework is analytically eclectic ${ }^{29}$ and internally coherent, provides determinate hypotheses, and is generalisable to similar cases.

Third, the article showcases the validity and explanatory power of the framework by testing it with the common UK-German Russia policy before and during the Brexit process up until mid-2019. To do so, the article uses structured and focused comparison as well as congruence analysis on data from British, German, and Russian primary sources in their respective original languages, such as foreign and security policy documents as well as interviews with stakeholders involved in policy formation. It complements these original sources with area studies, various datasets, and news reports.

Fourth, against the pessimists, the article finds that the common UK-German policy towards Russia strengthened after the Ukraine crisis and was not negatively affected by the Brexit process. The United Kingdom and Germany have concertedly confronted Russian incursions in Eastern Europe, increased military deterrence at its flanks, and imposed and maintained significant sanctions. Fifth, the article provides a comprehensive explanation of UK-German cooperation persistence towards Russia in the face of the Brexit process. It finds that the start of the Ukraine crisis caused strong convergence in UK-German threat perceptions towards Russia, mostly due to Germany moving towards the British position. Furthermore, it shows how both states sought to, and succeeded in, convincing each other of their continued reliability as allies by insulating the common Russia policy from the Brexit negotiations, effectively signalling solidarity, and increasing efforts within NATO and alternative security frameworks. Furthermore, the article shows that both sides saw each other as more capable allies during the Brexit process, as their formidable material capabilities remained more or less steady, while their respective influence in NATO (United Kingdom) and the EU (Germany) grew, which upgraded the value of good relations between the United Kingdom and Germany.

The rest of this article proceeds as follows. The next section develops the theoretical framework. The article then discusses methods and data. The next three sections apply the framework on three periods: before the start of the Ukraine crisis in 2014; before the Brexit referendum 2014 to 2016; and after the Brexit referendum 2016 to mid-2019. The penultimate section evaluates the overall results. The last section discusses the wider implications of the findings.

\section{Bilateral security and defence cooperation towards third states amid institutional disintegration}

The framework stipulates a flow of causes from the perceptions of individual allies (independent variables) towards the features that characterise their bilateral relations (intervening variables) resulting in trilateral relations, or the two allies' common policy towards a third state (dependent variable). The framework is summarised in Figure 1.

Dependent variable: The framework's dependent variable is the extent of bilateral security cooperation between two states towards a third state. ${ }^{30}$ This manifests itself as the common pursuit to ameliorate threats stemming from a third state. I distinguish three constitutive elements of such security cooperation - common goals, strategies, and efforts (see below). Bilateral

\footnotetext{
${ }^{29}$ Rudra Sil and Peter J. Katzenstein, 'Analytic eclecticism in the study of world politics: Reconfiguring problems and mechanisms across research traditions', Perspectives on Politics, 8:2 (2010), pp. 411-31.

${ }^{30}$ Used interchangeably here, such cooperation is sometimes also referred to as an alliance or alignment, see Stephen M. Walt, 'Why alliances endure or collapse', Survival, 39:1 (1997), p. 157.
} 


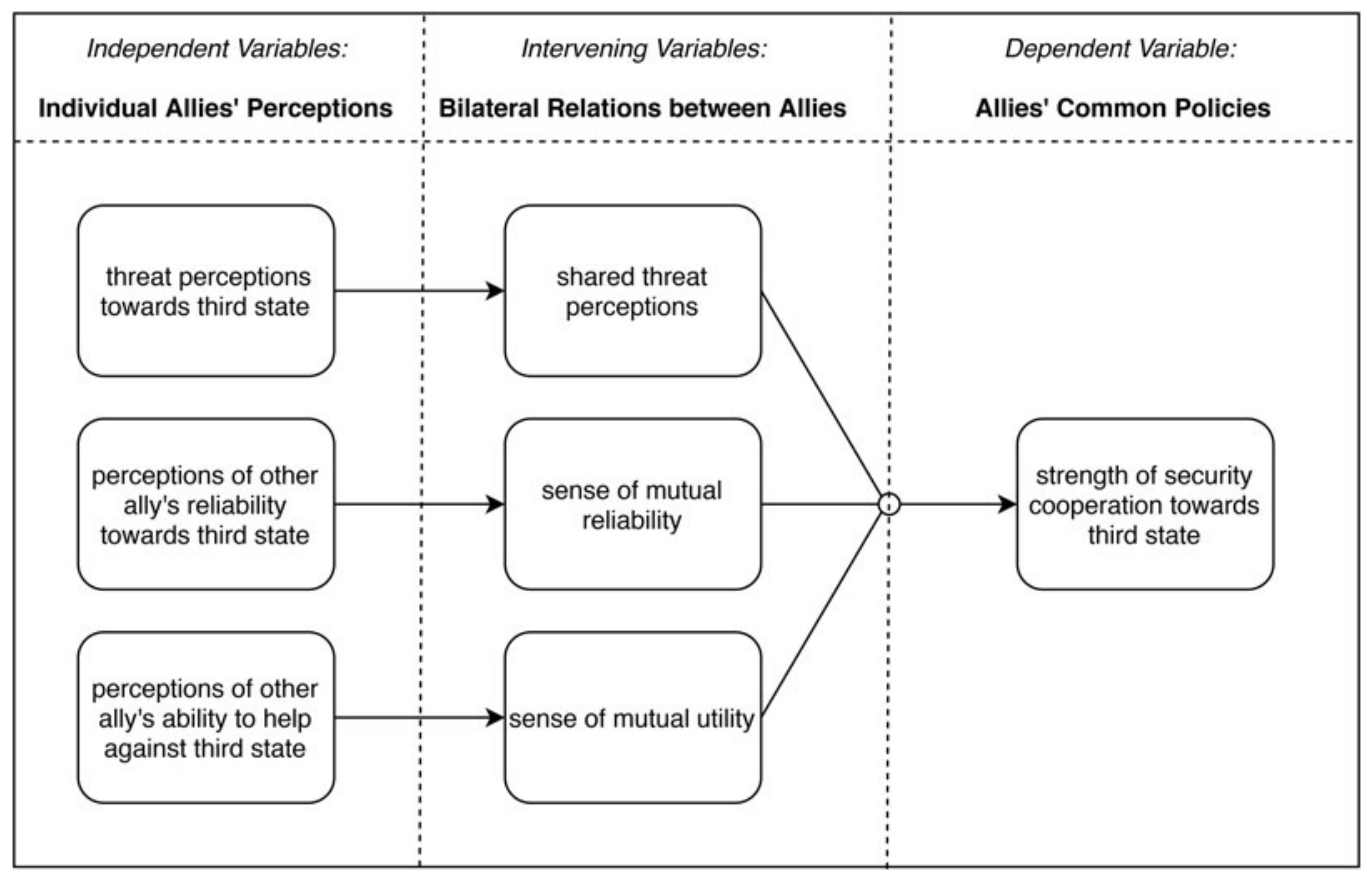

Figure 1. Theoretical framework on persistence of bilateral security and defence cooperation towards third states.

cooperation can be embedded in multilateral institutions and shared identities. States can be in multiple alignments with each other that can vary in their formality, strength, and function. For example, the United Kingdom and the United States are formally allied via NATO and a set of (other) formal international agreements. At the same time, they are informally aligned via their long-standing 'special relationship'. ${ }^{31}$ Overall alignment consists of all formal and informal alignment ties between two states. Henceforth, and if not specified otherwise, alliance and alignment is defined in this overall, aggregated, and bilateral sense. ${ }^{32}$ A bilateral alliance is 'multilaterally embedded' when two states share strong alignment ties which are, in part, based on shared membership in a wider alliance, but transcend this multilateral alliance via additional bilateral links. ${ }^{33}$

The framework further defines and disaggregates effective security cooperation towards third states into three constitutive elements. ${ }^{34}$ First, common goals: both states will give high priority in their policymaking and diplomatic attention to the threat towards which the alliance is designed. Second, common strategies: both states will largely agree on the means and strategies employed to counter the threat. Third, common efforts: both states will accord significant and similar degrees of effort (proportional to their capabilities) to counter the threat. In the presence of all these components, an alliance is active and effective. If either of these factors is weak or absent, an alliance

\footnotetext{
${ }^{31}$ Ruike Xu, Alliance Persistence within the Anglo-American Special Relationship: The post-Cold War Era (Basel: Springer, 2017).

${ }^{32}$ See also Jonas J. Driedger, 'Alliance persistence, military security and the 2016 Brexit referendum: The case of Estonia and the United Kingdom', in Baciu and Doyle (eds), Peace, Security and Defence Cooperation in Post-Brexit Europe, pp. 97-116.

${ }^{33}$ Ulrich Krotz and Joachim Schild, Shaping Europe: France, Germany, and Embedded Bilateralism from the Elysee Treaty to Twenty-first Century Politics (Oxford: Oxford University Press, 2015).

${ }^{34}$ Joint formation, coordination, and codification of policies can be a part of effective security cooperation but are not necessary elements of two states working towards the common goal of countering similar or same threats, as one state can simply align its strategies and efforts with the other, although it seems plausible that high degrees of shared strategies and efforts tend to be partially caused by processes of joint policy formation, coordination, and codification.
} 
will either lack a common purpose, a common approach, or meaningfully shared efforts and therefore be ineffective with regards to its original purpose.

Core assumptions: The causal framework rests on three basic assumptions. First, states generally act according to instrumental and embedded rationality. This means that, given their goals, perceptions, available information, and security culture, they will try to employ those strategies and means that they perceive to ensure their goals most effectively. ${ }^{35}$ Second, states always seek to achieve a modicum of 'security', meaning a low probability that their values - political autonomy, people, territory, and resources - will be destroyed, extorted, or their use coerced in any way. ${ }^{36}$ Note that this is a wider notion of security than that deployed in most realist accounts and allows for variation of what counts as security across states. ${ }^{37}$ Third, security cooperation always entails some costs, be it material, reputational, or in terms of freedom of action. ${ }^{38}$ Hence, when states enter alliances or remain within them, they calculate that doing so will provide them with some benefits.

Causal logic, mechanisms, and intervening variables: With security being an important state goal, security cooperation is conceptualised here as the effect of two states' individual preference to jointly deal with threatening third states. ${ }^{39}$ Consequently, the framework posits that bilateral security cooperation toward third states persists across time when the two allies continuously perceive the third state as a threat, when they expect that the other ally would support them against this threat, and when they view each other as capable of giving meaningful support in such a situation. The strength of security cooperation is hence determined by an interaction of three features of the two allies' bilateral relations: common threats, mutual utility, and mutual reliability. ${ }^{40}$ Insofar as ongoing processes of normative and institutional disintegration do not affect these variables, security cooperation should persist.

The first factor underlying effective and persistent alliances, shared threat perceptions, has long been considered a core determinant of the strength and persistence of alliances, notwithstanding disagreements among theorists on the exact determinants of threat perception and securitisation. ${ }^{41}$ Common threats solidify alliance strength because they focus the attention and efforts of both allies on a single third actor. In such a scenario, bargaining among allies is not about whether, but how to contain the third actor, and collective action problems are minimised. Consequently, given mutual utility and reliability, the higher the threat is that the third state presents simultaneously for both states, the stronger and more durable can the alliance be.

The second factor underpinning alliance strength and persistence is a shared sense of mutual reliability. ${ }^{42}$ Given sufficiently severe common threats and mutual utility, mutual reliability

\footnotetext{
${ }^{35}$ On instrumental rationality, see Frank C. Zagare, 'Rationality and deterrence', World Politics, 42:2 (1990), pp. $238-60$. On embedded rationality, see Emanuel Adler, 'Constructivism in international relations: Sources, contributions, and debates', in Walter Carlsnaes, Thomas Risse, and Beth A. Simmons (eds), Handbook of International Relations (London: SAGE Publications, 2012), pp. 112-44. On security cultures, see Peter J. Katzenstein (ed.), The Culture of National Security: Norms and Identity in World Politics (New York: Columbia University Press, 1996).

${ }^{36}$ David A. Baldwin, 'The concept of security', Review of International Studies, 23:1 (1997), pp. 5-26.

${ }^{37}$ Waltz, Theory of International Politics, pp. 116-28; John J. Mearsheimer, The Tragedy of Great Power Politics (updated edn, New York, NY: W. W. Norton, 2014).

${ }^{38}$ Walt, 'Why alliances endure or collapse', p. 158.

${ }^{39}$ Walt, 'Why alliances endure or collapse'.

${ }^{40}$ These three intervening variables derive from Xu, Alliance Persistence within the Anglo-American Special Relationship, pp. 19-47. The framework departs from Xu in that it specifies different independent variables and operationalises these indicators differently. See also Driedger, 'Alliance persistence, military security and the 2016 Brexit referendum'.

${ }^{41}$ Waltz, Theory of International Politics; Stephen M. Walt, The Origins of Alliances, Cornell Studies in Security Affairs (Ithaca, NY: Cornell University Press, 1987); Alexander Wendt, 'Anarchy is what states make of it: The social construction of power politics', International Organization, 46:2 (1992), pp. 391-425; Dan Reiter, 'Learning, realism, and alliances: The weight of the shadow of the past', World Politics, 46:4 (1994), pp. 490-526; Katzenstein (ed.), The Culture of National Security; Xu, Alliance Persistence within the Anglo-American Special Relationship.

${ }^{42} \mathrm{Xu}$, Alliance Persistence within the Anglo-American Special Relationship, p. 35.
} 
bolsters an alliance by providing states with a sense that they can count on their allies to receive significant help against the common threat. Absent such a sentiment, there would be no point in keeping up a costly alliance. The third factor underlying alliance strength is mutual utility. Given significant common threats and mutual reliability, states will maintain stronger alignment ties when they are able to significantly help each other in addressing their respective security concerns. ${ }^{43}$ Absent mutual utility, at least one state would calculate that the costs of the alliance exceed its expected benefits, which would weaken and ultimately render obsolete the alliance with regards to the third actor.

Independent variables: ${ }^{44}$ Three sets of independent variables reflect the perceptions of individual allies towards one another and towards the third state in question. Each intervening variable at the level of bilateral relations between the allies is determined by the lowest value of the constituent independent variables at the level of the individual ally. For example, the sense of mutual reliability between two allies will only be as high as the individual sense of reliability that the least trusting ally has of the other.

Operative perceptions about the degree to which another state represents a threat or a capable and reliable ally derive from interactions between the perceptual predispositions of the perceiving security elites and past behaviour of the other state in question. ${ }^{45}$ Most directly, such operative perceptions manifest empirically in a democratic state's foundational documents and the views of members of its security elite (see section on methods and data). The first independent variable, threat perceptions, increases when another actor exhibits a behavioural pattern that is processed as a sign of harmful intentions and is perceived to be capable of carrying out future harm. A state's sense of an ally's reliability, the second variable, increases when the ally, in past interactions, was perceived to have shown costly solidarity to the state in question or to the multilateral alliance in which the state is also a member. If the ally is perceived to have abstained from solidarity or even aggravated threats by its actions, it will be deemed a less reliable partner.

The third independent variable, a state's sense of an ally's utility, derives from perceptions about what the ally could do to ameliorate the threat stemming from the third state. ${ }^{46}$ Such an ability has two major components: the ally's own capabilities to increase resilience, weaken offensive capabilities of the third state, deter and disincentivise aggression; and the ally's ability to mobilise other states and cause them to ameliorate the threat. The next section will lay out how to operationalise these variables and measure them in the case of UK-German security cooperation towards Russia.

\section{Methods and data}

The analysis distinguishes three periods, or cases, according to variations in the independent and dependent variables: ${ }^{47}$ the period between Putin's ascent to power in 2000 up to the start of the

\footnotetext{
${ }^{43}$ Ibid.

${ }^{44}$ While the framework takes the intervening variables from $\mathrm{Xu}$, it finds his proposed independent variables underspecified and their derivation unsound. Xu derives shared threat perceptions ('shared anxiety') simply from 'external threats', mutual reliability from institutionalisation and collective identity, and mutual utility from the 'distribution of power'. Ibid.

${ }^{45}$ The framework itself is agnostic about the deeper determinants of perceptive predispositions, but is compatible with various accounts thereof, such as role and securitisation theory, first-image accounts, domestic construction, and security culture; see, for example, Katzenstein (ed.), The Culture of National Security; Krotz and Schild, Shaping Europe. Provided that its foundational assumptions are not violated, the framework is amendable and compatible with theories of perceptual change and securitisation, which can be used to specify the mechanisms by which its independent variables change.

${ }^{46}$ David A. Baldwin, 'Power and international relations', in Walter Carlsnaes, Thomas Risse-Kappen, and Beth A. Simmons (eds), Handbook of International Relations ( $2^{\text {nd }}$ edn, Oxford: SAGE, 2013), pp. 273-97.

${ }^{47}$ Cases are defined as an instance of a causal process playing out, linking a specific set of causes with an outcome. Hence, durations of cases can vary. See Derek Beach and Rasmus Brun Pedersen, Causal Case Study Methods: Foundations and Guidelines for Comparing, Matching and Tracing (Ann Arbor: University of Michigan Press, 2016), pp. 5-7.
} 
Ukraine crisis in 2014, the period before the Brexit referendum from 2014 to 2016, and a postreferendum period from 2016 to mid-2019. The following three sections provide analytical narratives for each period, organised around the framework's variables.

To apply and test the framework, two methods are employed. First, using structured and focused comparison, the article conducts a hoop test on the validity of the framework. If the values on the variables do not correspond with the correlations predicted by the framework, its validity would be disconfirmed. ${ }^{48}$ The comparison also serves to probe the validity of the rivalling pessimist views, which claim that the Brexit process weakened the common Russia policy. If the Russia policy would persist or even strengthen, the validity of pessimist views would be disconfirmed. Second, using congruence analysis, the article also assembles trace evidence to test the framework. Following Derek Beach and Rasmus Brun Pedersen, mechanisms are systems that transmit causal force from candidate causes, via entities engaging in activities, to produce an outcome. ${ }^{49}$ Hence, when relevant data is available, we should find trace evidence that transmits causal force from individual perceptions of threat, reliability, and utility towards the goals, strategies and efforts that comprise the common Russia policy of the United Kingdom and Germany. Finding evidence for such traces of the causal mechanism, especially when it has a high level of uniqueness and certainty, can strongly confirm or disconfirm the validity of the causal framework. ${ }^{50}$

As for measurements and data, primary sources are used where available. This includes original data from novel analysis of foundational policy documents on security and defence matters as well as interviews with British, German, and Russian top policymakers and experts involved in track II diplomacy. ${ }^{51}$ The assurance of anonymity reduced interviewees' incentives to misrepresent and allowed the interviewees to speak more freely about the regnant perceptions in their respective state apparatus. Conversely, the public and politicised nature of foundational policy documents in democracies indicates a close alignment between professed and actual perceptions, goals, and visions, as contradictions in rhetoric and action can undermine the government and empower its political opponents. This primary evidence is then triangulated with secondary sources, such as area studies, newspaper articles, and expert commentaries on the direction, intent, and intensity of the respective country's Russia policy. To minimise the danger of confirmation bias, three major bodies of research comparing the security and Russia policies of the United Kingdom and Germany were surveyed for evidence and arguments disconfirming the framework's validity. ${ }^{52}$ The analytical narratives include and discuss all data points that

\footnotetext{
${ }^{48}$ On evidence and causal inference in case-based research, see ibid., pp. 253-9.

${ }^{49}$ Ibid., pp. $34-41$.

${ }^{50}$ Ibid., pp. 154-226.

${ }^{51}$ Eighteen such original datapoints - eight interviewees and ten foundational documents respectively covering Russia, Germany, and the United Kingdom - are included in this analysis, which were part of a larger fieldwork project conducted in autumn and winter 2018/2019 in Moscow and other capitals of major European powers. All interviewees had regular contact with their respective head of government and foreign minister, as well as with the relevant counterparts in Moscow, Berlin, or London. Additional primary data was drawn from elite statements in news reports.

${ }^{52}$ Respectively, these three research projects employ consistent methods, approaches, and scopes that speak to the framework and minimise error variation between the total of ten detailed country studies they jointly comprise. The first project is a 2013 seminal comparative project on European perspectives and policies towards Russia before the 2014 events edited by David, Gower, and Haukkala, including David, 'Ireland and the United Kingdom'; Stewart, 'Germany'. The second is the Military Balance project with focused country studies on security and defence policies for Germany and the United Kingdom in 2012, 2015, and 2018, respectively; see International Institute for Strategic Studies, The Military Balance, 2012 (London: Routledge, 2012); International Institute for Strategic Studies, The Military Balance, 2015 (London: Routledge, 2015); International Institute for Strategic Studies, The Military Balance, 2018 (London: Routledge, 2018). The third is the seminal handbook by Meijer and Wyss on European armed forces and defence policies, including long-term studies on Germany's and the United Kingdom's defence policies up until 2018; see Dorman, 'The United Kingdom'; Ina Kraft, 'Germany', in Meijer and Wyss (eds), The Handbook of European Defence Policies and Armed Forces, pp. 53-70.
} 
could be argued to disconfirm the framework. As for confirming evidence, due to space constraints, only the most unique and certain evidence was included.

The elements of the common UK-German Russia policy - common goals, strategies, and efforts - are derived from the declared priorities in the respective country's foundational national security policy documents, and from interviews of practitioners involved in the formation and execution of their respective country's Russia policy. Threat perceptions are derived from foundational security documents and public statements of high-ranking politicians and state officials. If a third state is not named as a threat, this is not evidence of a lack of threat perception. However, due to the adverse diplomatic and domestic ramifications, publicly naming a third state as a threat is fairly robust evidence for the sincerity of the pronouncement.

Due to its high reputational costs and limited political value, foreign and security elites will rarely call a formally allied state 'unreliable', even if they feel this is the case. Consequently, direct evidence of unreliability is often not available. However, it is usually politically expedient to communicate a sense of strong reliability if there is one. Consequently, evidence for reliability was deduced from foundational security documents, interviews with practitioners, and public pronouncements of high-ranking politicians. Indirect evidence can be inferred from the past actions of allies: perceived acts of solidarity in the past attest to perceived reliability in the present, and a perceived lack of solidarity, let alone harmful behaviour, attests to a perceived lack of reliability in the present.

Two main indicators are used to establish the perceived utility of an ally. The first is the ally's material capabilities, such as disposable wealth, military equipment, and personnel. ${ }^{53}$ Material capabilities often represent the direct ability to help an ally by, for example, aiding its economy via foreign aid or bolstering its army via discounted and fast-tracked weapon sales. They can also aid an ally's security in indirect ways, such as rendering a capable ally more potentially dangerous to the third state and thus serving as a deterrent. Evidence for material capabilities are taken from the Military Balance database and from assessments by military experts and practitioners.

The second indicator for perceived utility is the ally's influence and leverage over other states, its institutional and soft power. ${ }^{54}$ States can use their good standing with other prospective allies to strengthen the coalition against the third state; they can also use a good standing with the threatening state to disincentivise aggression. Such influence is particularly important when only the ally holds such influence over the threatening state or capable potential allies. This also relates to relative influence in international institutions. The ability to mobilise members of such institutions and shape the policies of their members can be a major asset in addressing security challenges. Evidence for institutional and soft power is taken from expert assessments and evaluations from practitioners.

\section{Setting the stage: Disunity on Russia before the Ukraine crisis}

Overall assessment: Before 2014, Germany and the United Kingdom perceived each other as capable allies whose help in any contingency would be crucial. However, the United Kingdom regarded Russia as a significant threat, while Germany did not. This caused multiple situations that revealed a lack of mutual reliability between the two. In accordance with the theoretical framework, these diverging threat perceptions and a lacking sense of reliability resulted in a persistently weak common Russia policy.

Shared threat perceptions: The United Kingdom has perceived Russia as a potential threat well before the 2014 Ukraine crisis. In 2009, the House of Commons Defence Committee stated

\footnotetext{
${ }^{53}$ Walt, 'Why alliances endure or collapse'; Xu, Alliance Persistence within the Anglo-American Special Relationship, pp. 38-9.

${ }^{54}$ Baldwin, 'Power and international relations'; Ty Solomon, 'The affective underpinnings of soft power', European Journal of International Relations, 20:3 (2014), pp. 720-41.
} 
Russia could be a threat to Europe, although it did not deem Russia a 'direct existential threat' to the United Kingdom. ${ }^{55}$ In stark contrast, German security culture and construction of the Russian other permitted Russia's actions to be seen in a salvageable and even benign light. ${ }^{56}$ The German Ministry of Defence's Weißbuch of 2006, the only foundational document in this period exclusively designed to lay out German security and defence policy, comprises 165 pages, naming Russia 19 times, always in connection with the need and ongoing process of establishing and deepening security cooperation. ${ }^{57}$ There are no statements of Russia posing a threat in Europe.

Mutual reliability: Germany and the United Kingdom shared thick and long-lasting ties via the EU and NATO. However, these formal and institutional ties were not underpinned with shared threat perceptions, let alone a consensus on what would constitute a situation in which the two partners would aid each other vis-à-vis Russia. This resulted in cooperation failures and a subsequent lack of perceived reliability on both sides. For example, in 2006, a diplomatic crisis erupted between London and Moscow when former KGB/FSB agent Alexander Litvinenko, who had been granted British asylum and had alleged crimes against the Putin administration, was assassinated. London expelled four Russian diplomats, put restrictions on Russian visas and stopped counterterrorist cooperation. In return, the British ambassador in Moscow was harassed by youth groups close to the government. The EU, including Germany, showed only lukewarm solidarity with London. ${ }^{58}$

Mutual utility: To each other, the United Kingdom and Germany represented a major potential help in security contingencies involving Russia, due to their formidable power resources, which, apart from the United Kingdom's influence in the EU, persist throughout the whole period under investigation. In terms of institutional and soft power, both countries have major diplomatic clout in world affairs and the influential role they play in virtually every consequential international institution give them the ability to organise joint opposition against or support for other states. Both are members of the G7 and the G20, command a dense global network of embassies and consulates, and hold significant voting shares in the International Monetary Fund and the World Bank. The United Kingdom also holds a permanent seat at the UN Security Council and maintains a 'special relationship' with the United States, which, notwithstanding its questionable status as a security provider in Europe, remains by far the most powerful state on the globe. ${ }^{59}$ On the other hand, Germany's comparatively good relations with Russia and the formidable trade and energy ties between the two countries gave Germany some leverage in dealing with Russia. ${ }^{60}$

Material capabilities added to the United Kingdom's and Germany's mutual sense of utility, as the 2012 rows in Figure 2 illustrate. Shortly before the Ukraine crisis, the two countries' nominal GDP and military expenditure far exceeded that of Russia and their combined population equalled it. Taken together, the United Kingdom and Germany were able to field about half of what Russia could have fielded in terms of overall military personnel, main battle tanks, tactical aircraft, and combat ships. While the United Kingdom spent significantly more than Germany on defence, the average share of these indicators is more or less equal. On top of this, the United Kingdom commands a significant nuclear deterrent, as its Trident force can fire submarine-

\footnotetext{
${ }^{55}$ David, 'Ireland and the United Kingdom', p. 54.

${ }^{56}$ Stewart, 'Germany'.

${ }^{57}$ Germany, 'Weißbuch 2006. Zur Sicherheitspolitik Deutschlands und zur Zukunft der Bundeswehr' (2006), pp. 10, 24, 32, 52, 57, 59, available at: $\{$ https://www.google.com/url?sa=t\&rct=j\&q=\&esrc=s\&source=web\&cd=1\&ved=2ahUKEwjPveTrvevjAhUM 6KQKHRuZD-YQFjAAegQIBhAC\&url=http\%3A\%2F\%2Farchives.livreblancdefenseetsecurite.gouv.fr\%2F2008\%2FIMG\%2F pdf\%2Fweissbuch_2006.pdf\&usg=AOvVaw3T0HBLeZ1negRVCD3-8zOK\}.

${ }^{58}$ David, 'Ireland and the United Kingdom', pp. 55-6.

${ }^{59}$ United Kingdom, National Security Strategy and Strategic Defence and Security Review 2015: A Secure and Prosperous United Kingdom (2015), pp. 24, 34-6; United Kingdom Department for Exiting the European Union, 'Foreign Policy, Defence and Development: A Future Partnership Paper', policy paper (12 September 2017), p. 9, available at: \{https:// www.gov.uk/government/publications/foreign-policy-defence-and-development-a-future-partnership-paper\}; United Kingdom, National Security Capability Review: Including the Second Annual Report on Implementation of the National Security Strategy and Strategic Defence and Security Review 2015 (2018), p. 11; Dorman, 'The United Kingdom'.

${ }^{60}$ Stewart, 'Germany'; Forsberg, 'From Ostpolitik to "Frostpolitik"?'.
} 
launched nuclear missiles at strategic and substrategic targets. This includes four sophisticated submarine launched delivery systems with Moscow as their informal target. ${ }^{61}$ Adding further utility is Germany's formidable economy, which by far exceeded that of both the United Kingdom and Russia.

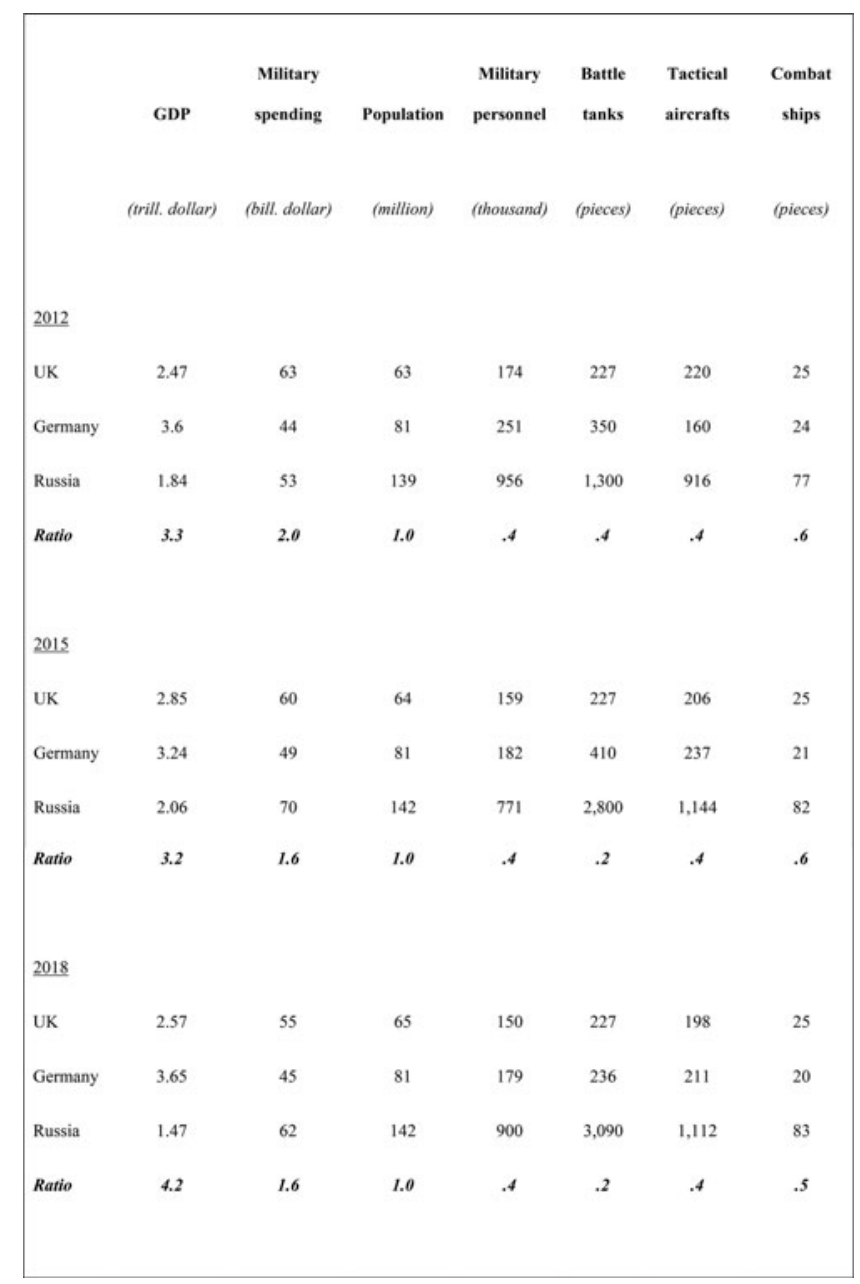

Figure 2. Russian, British, and German material capabilities, absolute numbers and ratio of combined UK-German capabilities as share of Russian capabilities, 2012, 2015, 2018.

Note: Data from the Military Balance Dataset. ${ }^{62}$ Ratio percentages are calculated by the author and represent the combined quantity of the United Kingdom and Germany in a given category and year as a percentage of that of Russia. GDP and military expenditure are in nominal rates and lagged one year. Note that nominal values likely undervalue Russian military expenditure due to its lower domestic prices of labour and goods. ${ }^{63}$ Similarly, the slump in Russian GDP between 2015 and 2018 is largely due to rising exchange rates. Only active military personnel and main battle tanks are included. Combat ships comprise cruisers, frigates, destroyers, aircraft carriers, and tactical submarines.

\footnotetext{
${ }^{61}$ Ian Davis, 'The British Bomb and NATO: Six Decades of Contributing to NATO's Strategic Nuclear Deterrent' (Stockholm International Peace Research Institute, 2015).

${ }^{62}$ International Institute for Strategic Studies, The Military Balance, 2012; International Institute for Strategic Studies, The Military Balance, 2015; International Institute for Strategic Studies, The Military Balance, 2018.

${ }^{63}$ Julian Cooper, 'Russia's Spending on Nuclear Weapons in a Comparative Perspective' (Oxford: Changing Character of War Centre, Pembroke College, University of Oxford, 19 October 2018).
} 
Common Russia policy: While both allies were officially committed to ensuring the security of fellow NATO and EU members as well as supporting democracy and human rights, the United Kingdom and Germany pursued largely dissimilar goals towards Russia, which caused them to adopt different strategies and employ their resources in different ways. This sometimes brought the United Kingdom and Germany into public opposition with each other. When Russia sought to quell Chechen separatism in the North Caucasus, committing gross human rights abuses in the process, the United Kingdom granted asylum to Chechen leader Akhmad Zakayev in 2003, and refused to extradite him to Russia. ${ }^{64}$ Germany, meanwhile, was reluctant to even criticise Russian conduct in Chechnya. ${ }^{65}$ In 2008, the United Kingdom lobbied towards granting Georgia and Ukraine a NATO Membership Action Plan (MAP), a policy strongly advocated by the United States and sharply resisted by Moscow. ${ }^{66}$ Germany, alongside France, opposed the Action Plan, again siding with Russia. ${ }^{67}$

The United Kingdom has traditionally taken an assertive and securitised approach towards Russia, usually siding with the United States when it came to condemning Russian actions. ${ }^{68}$ It has often used sanctions, sharp rhetoric, and international forums to curb Russia's influence, promote democracy and civil rights within Russia and deter Russian aggression. The 1999 Kosovo crisis, the 2003 Iraq War, the Libya intervention in 2011, the ongoing Syrian civil war - on all of these issues, the United Kingdom and the United States have taken a joint position and were met with fierce Russian opposition in the UN. ${ }^{69}$ The United Kingdom, in 2010, took the lead in forming the so-called Northern Group, which provides a forum for security and defence cooperation and includes all northern states proximate to Russia. This group includes even states that are not members of NATO, like Sweden and Finland, but also Lithuania, Latvia, and Estonia. ${ }^{70}$

Compared to the United Kingdom, Germany had pursued markedly different goals towards Russia, using significantly different strategies. Germany has long been perceived in the EU as a 'lawyer of Russian interests'. ${ }^{71}$ Starting in the early 2000 s and bolstered by a genuine friendship between German Chancellor Gerhard Schröder and Russian President Vladimir Putin, Russo-German economic relations received plenty of political attention and support, with trade growing rapidly between the two countries. ${ }^{72}$ This was undergirded with high-level symbols of cordiality and intensified intersocietal exchanges. ${ }^{73}$ For example, in 2001, Putin gave a very well-received speech to the German parliament, using the German language throughout the whole oration. ${ }^{74}$ When Angela Merkel became Chancellor in 2005, the political rhetoric towards Russia cooled, but Germany's actual policy towards Russia did not undergo major changes. ${ }^{75}$

\footnotetext{
${ }^{64}$ David, 'Ireland and the United Kingdom', pp. 56-7.

${ }^{65}$ Stewart, 'Germany', p. 18.

${ }^{66}$ 'Bush backs Ukraine on Nato bid', $B B C$ (1 April 2008), available at: $\{$ http://news.bbc.co.uk/2/hi/europe/7324035.stm\}; 'Nato denies Georgia and Ukraine', BBC (3 April 2008), available at: $\{$ http://news.bbc.co.uk/2/hi/europe/7328276.stm\}; 'EU allies unite against Bush over Nato membership for Georgia and Ukraine', The Independent (3 April 2008), available at: \{https://www.independent.co.uk/news/world/europe/eu-allies-unite-against-bush-over-nato-membership-for-georgia-andukraine-804000.html\}.

${ }^{67}$ Stewart, 'Germany', pp. 23-4.

${ }^{68}$ Author's interview with British Ministry of Defence official (October 2018).

${ }^{69}$ David, 'Ireland and the United Kingdom', p. 52.

${ }^{70}$ Elisabeth Braw, 'Europe's Northern Group', World Affairs Journal blog (11 June 2015), available at: \{http://www.worldaffairsjournal.org/blog/elisabeth-braw/europe\%E2\%80\%99s-northern-group\}.

${ }^{71}$ Trenin, 'Russia and Germany'; 'Wegen EU-Sanktionen: Russland wirbt um Investitionen aus China', Die Welt (9 July 2018), available at: \{https://www.welt.de/wirtschaft/article179007162/Wegen-EU-Sanktionen-Russland-wirbt-umInvestitionen-aus-China.html\}.

${ }^{72}$ Stewart, 'Germany', p. 17

${ }^{73}$ Ibid., pp. $16-17$.

${ }^{74}$ Ibid.

${ }^{75}$ Ibid., pp. 21-6; Forsberg, 'From Ostpolitik to "Frostpolitik”?', p. 24; Author's interview with two high-ranking German Ministry of Foreign Affairs officials (January 2019).
} 
Germany had long sought to further desecuritise relations with Russia, choosing economic and societal engagement over diplomatic and military assertion. ${ }^{76}$ Indeed, Germany strongly supported Russia in international forums, pushing Russia into the G7 (transforming it into the G8). Germany also opted to postpone its own G8 chairmanship to allow Russia to chair the group in 2006. ${ }^{77}$ In 2008, new Russian President Dmitry Medvedev and German Foreign Minister Walter Steinmeier packaged and upgraded several bilateral projects into a 'Modernization Partnership'. ${ }^{78}$ After the Russo-Georgian War of 2008, Germany was quick to support French President and President of the European Council Nicolas Sarkozy in mediating between Georgia and Russia (with Sarkozy basically freezing in Russian gains). ${ }^{79}$ Germany sought to return quickly to business as usual. ${ }^{80}$ While public rhetoric cooled over the start of Putin's controversial third presidential term and human rights violations in Russia, ${ }^{81}$ no major policy change occurred.

In line with its multilateral security culture, Germany had long sought to maintain a common EU and NATO approach towards Russia and has, at times, refrained from vetoing more assertive policies towards Russia to this end. Examples include Germany's acceptance of suspending the NATO-Russia Council after the Russo-Georgian $\mathrm{War}^{82}$ and uploading its 'Modernization Partnership' to the European level. ${ }^{83}$ However, this policy has been circumscribed when Germany saw national interests on the line. For example, and most prominently, Germany has resisted attempts to decrease economic links with Russia, especially in the energy sector. ${ }^{84}$ The Nord Stream pipeline projects, directly connecting Russia and Germany via the Baltic Sea, have been considered a grave security threat by the Baltics and Poland. Nonetheless, Germany continued to pursue these projects, both under Chancellors Schröder and Merkel. ${ }^{85}$

\section{The Ukraine shock: Convergence after 2014}

Overall assessment: Due to Russian conduct in Ukraine since 2014, including the occupation of Crimea, support for fighters in Donbas, and its conduct surrounding the downing of the Malaysian plane MH17, German threat perceptions towards Russia changed rapidly and converged with those of the United Kingdom. Both states signalled their mutual reliability by stating that they would support and advance assertive policies towards Russia, invoking a common European identity and using both NATO and EU structures in the process. Mutual utility persisted at a high level, as their relative material and institutional capabilities had remained virtually unchanged. Congruent with the theoretical framework, the converging threat perceptions and increasing sense of mutual reliability brought forth a much more united and assertive common Russia policy.

Shared threat perceptions: For the United Kingdom, the Ukraine crisis confirmed pre-existing threat perceptions towards Russia. In Britain's National Security Strategy and Strategic Defence and Security Review of 2015, Russia's conduct since 2010 is called 'more aggressive, authoritarian,

\footnotetext{
${ }^{76}$ Hans-Joachim Spanger, 'Die deutsche Russlandpolitik', in Thomas Jäger, Alexander Höse, and Kai Oppermann (eds), Deutsche Außenpolitik: Sicherheit, Wohlfahrt, Institutionen und Normen (Wiesbaden: VS Verlag für Sozialwissenschaften, 2011), pp. 648-72; Stewart, 'Germany'.

${ }^{77}$ Stewart, 'Germany'.

${ }^{78}$ Ibid., p. 23.

${ }^{79}$ Ronald D. Asmus, A Little War that Shook the World: Georgia, Russia, and the Future of the West (New York: Palgrave Macmillan, 2010).

${ }^{80}$ Stewart, 'Germany', pp. 23-4.

${ }^{81}$ Forsberg, 'From Ostpolitik to "Frostpolitik"?', pp. 26-8.

${ }^{82}$ Stewart, 'Germany', p. 26.

${ }^{83}$ Ibid., pp. $23-4$.

${ }^{84}$ Marco Siddi, 'Identities and vulnerabilities: The Ukraine crisis and the securitisation of the EU-Russia gas trade', in Kacper Szulecki (ed.), Energy Security in Europe (Basel: Springer International Publishing, 2018), pp. 251-73.

${ }^{85}$ Stewart, 'Germany'.
} 
and nationalist'. ${ }^{86}$ The document also referred implicitly to Russia's recent aggressions in Ukraine: 'Recent changes in the international security context remind us that we cannot relax our guard. We cannot rule out further shifts which would put us, or our NATO Allies, under grave threat. ${ }^{, 87}$

With the 2014 Ukraine crisis, Germany's comparatively optimistic and non-securitised perception of Russia transformed into one of threat and pessimism, converging rapidly towards that of the United Kingdom. High-ranking German diplomats working on Russia and Eastern Europe attest that German threat perceptions towards Russia have risen significantly since $2014 .^{88}$ This is also evinced by the provisions of the 2016 Weißbuch. ${ }^{89}$ In the document, Russia and its policies, as well as the methods of hybrid war, are perceived as 'a threat to the European peace order [europäische Friedensordnung]', with significant consequences for security in Europe and therewith [und damit auch] also for Germany's own security. ${ }^{90}$

Mutual reliability: With the start of the Ukraine crisis, Germany and the United Kingdom increasingly perceived each other as reliable partners, as common identities and institutional ties were now frequently invoked and utilised to enact new common policies towards Russia. Before the crisis, the Russia policy within both NATO and the EU represented little more than an abstract, formal, and declarative consensus. This changed with the crisis, where both institutions became platforms for assertive and unified policies as well as the focal point for expressions of unity and solidarity, ${ }^{11}$ with the United Kingdom calling Russia a threat to NATO allies, and Germany denoting it as a threat to the European peace order (see shared threat perceptions).

Mutual utility: Mutual utility remained at a comparatively high level. Institutional and soft power assets as well as the ratio of material capabilities between the United Kingdom and Germany remained virtually unchanged, as did their combined weight as compared to that of Russia (see Figure 2, row 2015).

Common Russia policy: From 2014 onwards, the Ukraine crisis caused significant convergence between British and German goals, strategies and efforts towards Russia. This was mainly a result of Germany's goals, strategies, and efforts aligning with those of the United Kingdom. Most notably, both states were instrumental proponents and contributors to a series of NATO policies that condemned and punished Russian aggression while aiming to increase deterrence of future Russian incursions. The United Kingdom agreed to send combat troops to Estonia and act as a leader and framework nation for other NATO allies in Estonia. ${ }^{92}$ Germany, for its part, took the unprecedented move and pledged to contribute NATO combat troops as tripwire forces in Lithuania to deter and defend against Russian aggression. ${ }^{93}$

The United Kingdom and Germany were also crucial supporters of new and assertive EU actions towards Russia. Due to its traditionally Russia-friendly policy, its formidable influence within the EU, and its economic clout, Germany was also an instrumental driving force behind

\footnotetext{
${ }^{86}$ United Kingdom, National Security Strategy and Strategic Defence and Security Review 2015, p. 18.

${ }^{87}$ Ibid., p. 34.

${ }^{88}$ Author's interview with two high-ranking German Ministry of Foreign Affairs officials.

${ }^{89}$ Although this Weißbuch was published three weeks after the Brexit referendum, it reflects the perception of the security of the Federal Republic of Germany even before it, as these documents are produced over the course of months and require redactions and acceptance at all levels and from all relevant agencies.

${ }^{90}$ Germany, 'Weißbuch 2016. Zur Sicherheitspolitik und zur Zukunft der Bundeswehr' (2016), pp. 31-2, available at: \{https://www.bmvg.de/resource/blob/13708/015be272f8c0098f1537a491676bfc31/weissbuch2016-barrierefrei-data.pdf\}.

${ }^{91}$ Author's interview with British Ministry of Defence official, 2018; author's interview with two high-ranking German Ministry of Foreign Affairs officials, 2019, see also common Russia policy below.

${ }^{92}$ Robin Emmott and Sabine Siebold, 'NATO agrees to reinforce eastern Poland, Baltic States against Russia', Reuters (9 July 2016), available at: \{https://uk.reuters.com/article/uk-nato-summit/nato-agrees-to-reinforce-eastern-poland-balticstates-against-russia-idUKKCN0ZN2NN\}.

${ }^{93} \mathrm{Kraft}$, 'Germany'.
} 
bringing about, toughening, and maintaining sanctions against Russia. ${ }^{94}$ Since their introduction on 31 July 2014, EU sanctions have been repeatedly renewed and strengthened before and after the Brexit referendum. These sanctions and the ensuing Russian countersanctions have harmed both the German and UK economy. Simultaneously, major financial and energy sanctions were precluded, with the United Kingdom, Germany, and Russia protecting their respective core economic interests and accepting that their counterparts did so as well. ${ }^{95}$

Analogous to its changing perceptions, Germany took a much more assertive and securitised approach towards Russia, while retaining its long-standing emphasis on multilateral action. High-ranking German officials involved in the formation of Germany's Russia policy characterise the changes in Germany's Russia policy since 2014 as a 'paradigm shift'. ${ }^{96}$ Having been its most ardent proponent in the past, Germany now supported Russia's expulsion from the G8 and the suspension of Russian voting rights in the Council of Europe. ${ }^{97}$ Russian decision-makers and experts were strongly dismayed by this German conduct and the traditionally cordial rhetoric between the two countries deteriorated. ${ }^{98}$

This policy convergence on Russia since 2014 has also caused a shift in how the Russian foreign and security elite views the United Kingdom and Germany, with the former being perceived as a continuously aggressive proxy of a hegemonic United States, and the latter as a less and less reliable mediator between the supposedly aggressive United States and Russia. ${ }^{99}$

Security cooperation did not strengthen in all areas. Germany retained some elements of its traditional Russia policy and did not abandon all measures of engagement. For example, Germany, and its traditional ally France, were instrumental in bringing about the Minsk accords and the Normandie process, which was favoured by Russia and disliked by Ukraine. The United Kingdom did not become a part of the Normandy format. However, British and German policymakers report a high degree of policy coordination with London and neither side saw the United Kingdom's abstention as an act of exclusion. ${ }^{100}$ The 2016 Weißpapier of the German Armed Forces urged the facilitation of 'cooperative security' and 'sectoral collaboration' with Russia. ${ }^{101}$ The 2 per cent NATO Wales Summit target, although agreed upon, was ambiguously perceived in the German political establishment. Nonetheless, since 2014, defence spending in Germany has steadily increased. ${ }^{102}$

\footnotetext{
${ }^{94}$ Ulrich Speck, 'German Power and the Ukraine Conflict', Carnegie Europe (26 March 2015), available at: \{https://carnegieeurope.eu/2015/03/26/german-power-and-ukraine-conflict-pub-59501\}.

${ }^{95}$ Erica Moret and Maruša Tekavčič Veber, The New Deterrent?: International Sanctions against Russia over the Ukraine Crisis: Impacts, Costs and Further Action (Graduate Institute of International and Development Studies, 2016); Masha Hedberg, 'The target strikes back: Explaining countersanctions and Russia's strategy of differentiated retaliation', Post-Soviet Affairs, 34:1 (2018), pp. 35-54; 'Instrument der Außenpolitik - Wie wirksam sind Sanktionen?', Deutschlandfunk (15 February 2018), available at: \{https://www.deutschlandfunk.de/instrument-der-aussenpolitik-wie-wirksam-sind-sanktionen.724.de.html?dram:article_id=410884\}.

${ }^{96}$ Author's interview with two high-ranking German Ministry of Foreign Affairs officials.

${ }^{97}$ 'U.S., other powers kick Russia out of G8', CNN (25 March 2014), available at: \{https://www.cnn.com/2014/03/24/politics/obama-europe-trip/index.html\}; 'Russia delegation suspended from Council of Europe over Crimea', The Guardian (10 April 2014), available at: \{https:/www.theguardian.com/world/2014/apr/10/russia-suspended-council-europe-crimeaukraine\}.

${ }^{98}$ Trenin, 'Russia and Germany'; Die Welt, 'Wegen EU-Sanktionen'.

${ }^{99}$ Author's interview with Russian Ministry of Foreign Affairs official, December 2018; author's interview with senior Russian security expert at a major Russian security and foreign policy think tank, December 2018; author's interview with Russian Ministry of Foreign Affairs official, January 2019; author's interview with two Russian security experts at a major Russian security and defence think tank, December 2018.

${ }^{100}$ Author's interview with two high-ranking German Ministry of Foreign Affairs officials; author's interview with British Ministry of Defence official.

${ }^{101}$ Germany, 'Weißbuch 2016', pp. 31-2.

${ }^{102}$ International Institute for Strategic Studies, The Military Balance, 2015, 2018.
} 


\section{Protecting the new consensus during the Brexit process}

Overall assessment: After the 2016 Brexit referendum, the United Kingdom and Germany continued to jointly perceive Russia as a major threat to their own security and that of their allies, mainly due to Russia's conduct towards Ukraine. Mutual reliability had increased, as both sides had observed the other asserting common values and interests towards Russia in the immediate aftermath of the Ukraine crisis. With the Brexit referendum, mutual utility also increased, as Germany prospectively gained more relative influence in the EU, just as the United Kingdom did within NATO. In accordance with the theoretical framework, this rise in mutual reliability and utility strengthened the common Russia policy of the United Kingdom and Germany, despite of the corrosive effects that other processes endogenous to Brexit might have had.

Shared threat perceptions: British and German threat perceptions remained largely unchanged and continued to be mostly congruent. In its National Security Capability Review of March 2018, the United Kingdom again stressed the 'resurgence of state-based threats' and gave as the first and most prominent example a 'well-established pattern of Russian State aggression'. ${ }^{103}$ The 2018 German Governmental Coalition Agreement echoed the 2016 Weißbuch statement that through 'the annexation and its involvement in Eastern Ukraine, Russia violates the European peace order [europäische Friedensordnung]. ${ }^{104}$

Mutual reliability: Two lines of evidence attest to a rising sense of mutual reliability between the two allies. Both were corroborated by British and German officials working closely on relations with Russia. ${ }^{105}$ First, in rhetoric, spending, and action, both sides increased their efforts within NATO. The United Kingdom in particular has always had the reputation and declared policy of preferring NATO over EU frameworks as the core instrument of military security in Europe. ${ }^{106}$ Right after the referendum, outgoing British Prime Minister David Cameron pledged at a NATO summit that the United Kingdom would keep its commitment to European security even after leaving the EU. ${ }^{107}$ During the same time period, British Defence Secretary Michael Fallon, with reference to British NATO deployments to Estonia, stated that, '[NATO] is the cornerstone of our defence ... we'll be doing more in [NATO] to compensate for our withdrawal from the EU. That's the purpose of the deployment we're announcing today. ${ }^{108}$ Since the referendum, the United Kingdom has also repeatedly restated its commitment to use its nuclear Trident forces to protect NATO allies. ${ }^{109}$

Germany also renewed and increased its NATO commitment, sending combat troops to Lithuania. In the 2018 Coalition Agreement, the signatories stated that 'NATO remains an indispensable guarantor and is the foundation of our security. Germany is and will remain a reliable partner in the alliance. We want to strengthen the European contribution to the transatlantic

\footnotetext{
${ }^{103}$ United Kingdom, National Security Capability Review: Including the Second Annual Report on Implementation of the National Security Strategy and Strategic Defence and Security Review 2015, p. 6.

${ }^{104}$ Germany, 'Weißbuch 2016', p. 31; Germany, 'Koalitionsvertrag zwischen CDU, CSU und SPD 19. Legislaturperiode' (12 March 2018), pp. 149-50, available at: \{https://www.bundesregierung.de/resource/blob/975226/847984/ 5b8bc23590d4cb2892b31c987ad672b7/2018-03-14-koalitionsvertrag-data.pdf?download=1\}.

${ }^{105}$ Author's interview with British Ministry of Defence official; author's interview with two high-ranking German Ministry of Foreign Affairs officials.

${ }^{106}$ Carmen-Cristina Cîrlig and Laura Puccio, 'The Future Partnership between the European Union and the United Kingdom: Negotiating a Framework for Relations after Brexit' (Brussels: European Parliamentary Research Service, September 2018), pp. 78-81; author's interview with British Ministry of Defence official; Kaljurand et al., Brexit and Baltic Sea Security, pp. 18-20.

${ }^{107}$ Emmott and Siebold, 'NATO agrees to reinforce eastern Poland, Baltic States against Russia'.

${ }^{108}$ Jessica Elgot and Claire Phipps, 'Cameron names Sir Julian King as UK's new EU commissioner', The Guardian (8 July 2016), available at: \{https://www.theguardian.com/politics/live/2016/jul/08/theresa-may-next-prime-minister-andrea-leadsom-politics-live?page=with:block-577f6b23e4b04ae4a10b9ab0

${ }^{109}$ United Kingdom, National Security Strategy and Strategic Defence and Security Review 2015, pp. 24, 34-6; United Kingdom, 'Foreign Policy, Defence and Development', p. 9; United Kingdom, National Security Capability Review, p. 11.
} 
partnership and we are committed to closer cooperation between NATO and the EU. ... Germany will continue to make an appropriate contribution to the preservation of the alliance's deterrence and defence capabilities and to a strong European defence. ${ }^{110}$

Second, mutual reliability since the referendum has been solidified through mutual symbolic reassurances and new forms of British-German security cooperation. The United Kingdom aimed to quickly negotiate a hitherto unprecedentedly comprehensive security and defence deal with the EU. ${ }^{111}$ It also sought additional institutional frameworks outside of the EU and NATO to pursue its Russia policy. Since 2016, British decision-makers repeatedly stressed the firm commitment to Northern security frameworks. ${ }^{112}$ In September 2017, the United Kingdom explicitly reiterated its security commitments to the Nordic countries. ${ }^{113}$ In June 2018, the United Kingdom joined the European Intervention Initiative (EII) along with Germany, Belgium, Denmark, the Netherlands, Estonia, Spain, Portugal, and France, which had spearheaded the project. The EII works outside EU as well as NATO frameworks and aims at ensuring coordination among national armed forces and rapid reactions in critical situations. ${ }^{114}$ Signalling its commitment to UK security, Germany expelled four Russian diplomats over the poisoning of Sergei Skripal in 2018. German Foreign Minister Heiko Maas declared this to be an act of solidarity to the United Kingdom. While the United States and Ukraine expelled more Russian diplomats over the Skripal case, many EU member states expelled fewer, while, notably, Italy and Austria expelled none. ${ }^{115}$ This stands in stark contrast to the EU's and Germany's lukewarm reaction to the UK-Russian confrontation over the Litvinenko assassinations in 2006 (see section 4, reliability).

Mutual utility: After the referendum, perceived utility between the United Kingdom and Germany rose. This is mostly due to an increase in perceived soft and institutional power. The United Kingdom's prospective exit from the EU entailed that the relative influence of the EU and its members within NATO would weaken, while that of non-EU powers would rise even more. With the United Kingdom, NATO's two most militarily capable states will not be EU-members. As the build-up of EU 'Strategic Autonomy' is at most a future project and bedazzled with many structural problems, ${ }^{116}$ good relations to the United Kingdom, as a non-EU member and due to its 'special relationship' with the United States, becomes more important, especially for a multilaterally oriented actor such as Germany. With the prospective exit of the United Kingdom from the EU, Germany's already towering influence within the EU is bound to increase even further. ${ }^{117}$ This comes at a time where Italy and France face economic problems and political infighting, further pronouncing Germany's role within the EU. The EU commands considerable economic power and influence in the world, which renders good relations with Germany a major foreign and security policy asset for the United Kingdom.

Rising mutual utility is evinced by the constant and determined diplomatic overtures by both sides to quickly form supplementary UK-EU ties in the security area to compensate for Brexit,

\footnotetext{
${ }^{110}$ Germany, 'Koalitionsvertrag zwischen CDU, CSU und SPD', pp. 147-8, author's translation.

${ }^{111}$ Alex Barker, 'EU and UK seek speedy Brexit deal on defence and security', Financial Times (4 February 2018), available at: $\{$ https://www.ft.com/content/cdf96d34-066f-11e8-9650-9c0ad2d7c5b5\}.

${ }^{112}$ Author's interview with British Ministry of Defence official; Kaljurand et al., Brexit and Baltic Sea Security, pp. 18-20.

${ }^{113}$ William James, 'UK says defense commitment in Nordic and Baltic States won't waver after Brexit', Reuters (3 September 2017), available at: \{https://uk.reuters.com/article/uk-britain-eu-security/uk-says-defence-commitment-in-nordic-and-baltic-states-wont-waver-after-brexit-idUKKCN1BE16T\}.

${ }^{114}$ Cîrlig and Puccio, 'The Future Partnership between the European Union and the United Kingdom', p. 88.

${ }^{115}$ 'Reaktion auf Giftgas-Anschlag: USA und EU weisen Dutzende russische Diplomaten aus', Handelsblatt (26 March 2018), available at: \{https://www.handelsblatt.com/politik/international/reaktion-auf-giftgas-anschlag-usa-und-eu-weisendutzende-russische-diplomaten-aus/21115238.html\}.

${ }^{116}$ Jolyon Howorth, 'Strategic autonomy and EU-NATO cooperation: Threat or opportunity for transatlantic defence relations?', Journal of European Integration, 40:5 (2018), pp. 523-37.

${ }^{117}$ Krotz and Maher, 'Europe's crises and the EU's "Big Three"'.
} 
with explicit references to the need to cooperate towards Russia. ${ }^{118}$ On 5 October 2018, UK Secretary of Defence Gavin Williamson joined his German counterpart Ursula von der Leyen in Minden, where they signed a 'Joint Vision Statement'. This bilateral declaration on closer cooperation in security and defence policy was intended to provide the framework for further joint projects, such as improving the interoperability of the two armed forces, deepening cooperation in the development of capabilities, as well as more joint training and exercises. ${ }^{119}$

While the mutually perceived soft and institutional power rose, perceptions of utility stemming from material capabilities remained steady. Across the main indicators, overall material capabilities of the United Kingdom and Germany decreased somewhat from 2015 to 2018. However, the combined weight of the United Kingdom's and Germany's material capabilities towards those of Russia remained basically unchanged, as did their relative share in the aggregate across these indicators (see Figure 2, rows 2015 and 2018).

Common Russia policy: The Brexit referendum did not negatively affect the UK-German Russia policy in any significant and measurable way. Most importantly, the Russian foreign and security elite does not seem to believe that the Brexit process caused a weakening of the UK-German Russia policy. ${ }^{120}$ Furthermore, the language in the foundational security documents about the goals towards Russia on both sides continued to be highly similar, which suggests active coordination preceding the formulation of them. The EU Global Strategy of 2016, which was drafted before the referendum and released right after it, stated that '[managing] the relationship with Russia represents a key strategic challenge. A consistent and united approach must remain the cornerstone of EU policy towards Russia. ${ }^{121}$ On 2 March 2017, the UK House of Commons Foreign Affairs Committee (FCO) released a paper on the United Kingdom's relations with Russia that featured an assessment that matched the EU Global Strategy:

The international community must remain unified in the face of Russia's assertion of its perceived sphere of influence and its disregard for the international norms in its treatment of Ukraine. The FCO should ... continue to work closely with EU partners to maintain support for Ukraine, whether this is delivered through sanctions and/or assistance to Ukraine. $^{122}$

Strategies and efforts towards Russia remained similar or converged even further after the Brexit referendum. Sanctions against Russia were routinely supported by both the United Kingdom ${ }^{123}$ and Germany and consequently renewed every half year. Both sides sought to prevent a weakening of sanctions in the absence of Russian compliance on the Minsk agreements. A 2017 UK House of Commons report stated that withdrawal of the existing sanctions should be linked to Russian compliance with its obligations toward Ukraine, and should not be offered in exchange for Russian co-operation in other areas. ${ }^{124}$ Similarly, in 2018, the new Federal Coalition Agreement of Germany's ruling parties stated that cancellation of the main package

\footnotetext{
${ }^{118}$ United Kingdom, 'Foreign Policy, Defence and Development'.

${ }^{119}$ German Ministry of Defence, 'Ministerin zeichnet mit britischem Amtskollegen Joint Vision Statement' (8 October 2018), available at: \{https://www.bmvg.de/de/aktuelles/ministerin-zeichnet-mit-britischem-amtskollegen-joint-vision-statement-28180\}.

${ }^{120}$ Author's interview with Russian Ministry of Foreign Affairs official, December 2018; author's interview with Russian Ministry of Foreign Affairs Official, January 2019.

${ }^{121}$ European Union, 'Shared Vision, Common Action: A Stronger Europe. A Global Strategy for the European Union's Foreign and Security Policy' (June 2016), p. 33.

${ }^{122}$ UK House of Commons Foreign Affairs Committee, 'The United Kingdom's Relations with Russia' (2 March 2017), p. 61.

${ }^{123}$ Patrick Wintour, 'Jeremy Hunt calls for fresh EU sanctions against Russia', The Guardian (21 August 2018), available at: \{https://www.theguardian.com/politics/2018/aug/21/hunt-to-call-on-trump-to-impose-fresh-sanctions-on-russia\}.

${ }^{124}$ UK House of Commons Foreign Affairs Committee, 'The United Kingdom's Relations with Russia', pp. 60-1.
} 
of sanctions should be contingent on Russia implementing the Minsk Agreements. ${ }^{125}$ Both documents emphasised the need to maintain a unified front amid the ongoing political turbulence in Europe, with the British one explicitly stating that the common Russia policy should be insulated as far as possible from the ongoing Brexit negotiations. The United Kingdom has also since undertaken steps to impose additional unilateral sanctions on Russian individuals involved in gross human rights abuses. ${ }^{126}$ The United Kingdom is also actively assessing how to pursue sanctions (hitherto couched in an EU framework) after a finalised Brexit. ${ }^{127}$

Both the United Kingdom and Germany have increased their efforts to cooperate towards Russia in the context of NATO. In 2017, Operation Enhanced Forward Presence started in the Baltics. ${ }^{128}$ The United Kingdom provides most combat troops and acts as lead nation in Estonia, with Germany doing the same in Lithuania. NATO, under general secretary Jens Stoltenberg, has sharply condemned Russian deployments of intermediate missiles and its conduct in the Kerch strait in late 2018. ${ }^{129}$ This also reflects an underlying unity of the NATO members, which include most of the old EU member states as well as the United Kingdom and Germany. ${ }^{130}$

Despite this ongoing convergence, some elements of Germany's Russia policy remain at odds with that of the United Kingdom. The United Kingdom remained outside the Normandy Group. In the first half of 2018, the German federal government coordinated the construction of the Nord Stream 2 gas pipeline and resisted numerous attempts from EU and NATO partners to stop construction. ${ }^{131}$

\section{Brexit, Russia, and cooperation persistence amid institutional disintegration}

Figure 3 gives an overview of how the actual strength of UK-German security cooperation towards Russia over time relates to the predictions on correlations derived from the theoretical framework and the rivalling pessimist positions. Values are arrived at by drawing on the analytical narratives and comparing relative differences across time and countries. For example, German threat perception towards Russia rose significantly due to Russian actions towards Ukraine since 2014 and became virtually indistinguishable with that of the United Kingdom, rising from 'low' before 2014 to 'high' thereafter. While the various pessimist positions simply predict a weakening common Russia policy after 2016, the framework predicts that the strength of the common Russia policy will correlate with the lowest value on either of the three intervening variables in a given period. The common Russia policy was weak and ineffectual before 2014. It gained strength with the start of the Ukraine crisis, and became even more unified and assertive after the Brexit referendum, even though some possible elements of a more robust Russia policy remained unrealised, such as Germany agreeing to extend sanctions to the gas sector, or the United Kingdom inserting itself in the Minsk process. Overall, the permutations of the variables disconfirm pessimist positions and corroborate the theoretical framework.

The balance of trace-evidence listed in the analytical narratives further corroborates the framework's validity and indicates that the correctly predicted correlations in Figure 3 reflect the causal mechanisms stipulated by the framework. While evidence was not available to test

\footnotetext{
${ }^{125}$ Germany, 'Koalitionsvertrag zwischen CDU, CSU und SPD', p. 150.

${ }^{126}$ UK House of Commons Foreign Affairs Committee, 'The United Kingdom's Relations with Russia', pp. 61-2.

${ }^{127}$ Ibid., p. 63.

${ }^{128}$ For information on Operation Enhanced Forward Presence, see: $\{$ https://shape.nato.int/efp\}.

${ }^{129}$ NATO, 'Press Conference by NATO Secretary General Jens Stoltenberg ahead of the meetings of NATO Ministers of Foreign Affairs' (3 December 2018), available at: \{http://www.nato.int/cps/en/natohq/opinions_161037.htm\}.

${ }^{130}$ 'NATO pledges support for Ukraine over Sea of Azov incident', RadioFreeEurope/RadioLiberty (13 December 2018), available at: $\{$ https://www.rferl.org/a/nato-pledges-support-ukraine-azov-sea-incident/29654701.html\}.

${ }^{131}$ 'Umstrittene Gaspipeline: Kanzlerin drückt Nord Stream 2 durch', Spiegel Online (8 February 2019), available at: \{https://www.spiegel.de/politik/ausland/nord-stream-2-angela-merkel-setzt-gas-pipeline-in-der-eu-durch-a-1252366.html\}.
} 


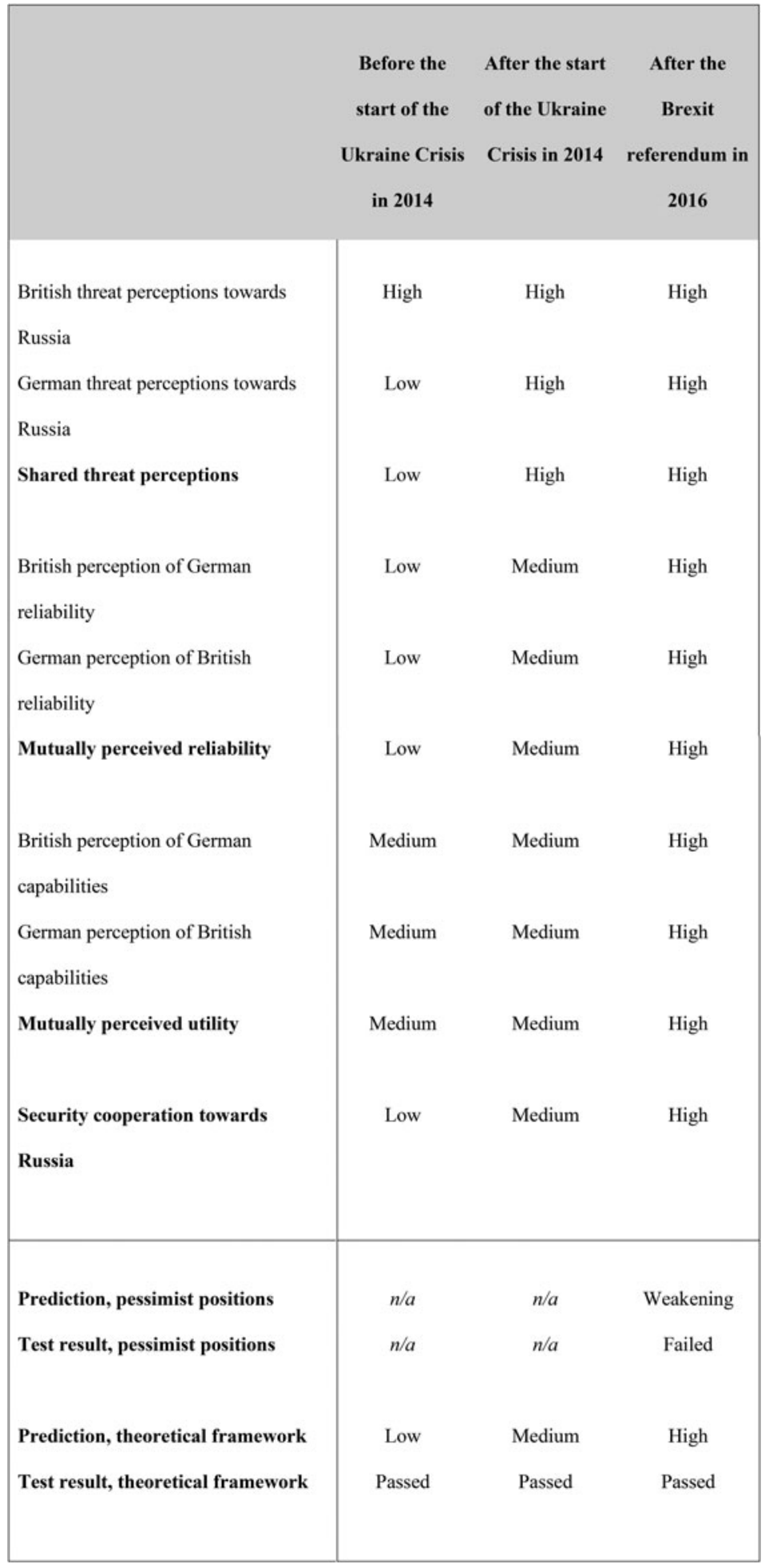

Figure 3. Hoop test results. Determinants and nature of the common UK-German Russia policy from 2000 to mid-2019. 
for the causal mechanisms in all conceivable instances, no decisive disconfirming evidence was found, while corroborating evidence was abundant. The divergence in German and British goals, strategies, and efforts towards Russia before the start of the Ukraine crisis can be directly traced to dissimilar perceptions, with the United Kingdom perceiving Russia as a threat to be guarded against, while Germany saw Russia largely as a misunderstood security partner in the making. The Ukraine crisis, measurably and drastically, changed the German threat calculus, as not even Germany's pacifistic and civilian security culture allowed a benign interpretation of Russian behaviour. Both the United Kingdom and Germany started to use NATO and the $\mathrm{EU}$ as platforms to guard against future Russian aggression, thereby inadvertently signalling commitment and reliability to each other. With the Brexit referendum, these converging threat perceptions and increasing sense of mutual reliability was met with a rising sense of mutual utility due to the now more prominent roles that Germany would play in the EU and the United Kingdom within NATO.

Combined, these findings demonstrate that proposed mechanisms of normative and institutional disintegration did not measurably diminish continued security cooperation towards Russia. Rather, amid time-consuming and partially hostile negotiations during the Brexit process, trace evidence indicates that both the United Kingdom and Germany took active steps to insulate and protect the common Russia policy from these effects due to threat perceptions towards Russia and mutual perceptions of utility and reliability (see the subsection on the common Russia policy in the preceding section).

\section{Conclusions and implications}

Beyond confirming the validity of the theoretical framework and explaining the common UK-German Russia policy between 2000 and mid-2019, the results of this study have four political and theoretical implications. First, while the study did not systematically investigate the deeper causes of British conduct, a long-lasting construction of Russia as a significant threat and of the United Kingdom as an assertive, Western, and liberal great power have clearly played a key role in giving continuity to British policy towards Russia since the early 2000s and throughout major policy crises such as the war in Ukraine, the election of Donald Trump as President of the United States, and the Brexit referendum. These causal forces are likely to remain operative in the future and insulate British policy towards Russia from major changes in British domestic politics and future tensions between the United Kingdom and the EU.

Second, due to changes in threat perceptions, German security policy towards Russia has drastically changed since 2014, despite the extensive and mutually lucrative gas trade between the two. This evident determination renders Germany a likely future focal point of European efforts to guard against Russia. However, as this study as well as ongoing German reluctance to become more engaged in Syria and against Iran show, this is contingent on specific and regionally confined threat perceptions. German multilateralism and its preference for non-military means persists, but these factors translate to different, and indeed more assertive, policies when it comes to Russia within Europe, which is now seen as a direct threat to Germany and its partners.

Third, trace evidence showcases that cooperation towards Russia persisted at least in part due to country-specific perceptual predispositions. However, this does not preclude, and is complementary with, James Sperling's and Mark Webber's argument that collective securitisation processes within NATO, of which both the United Kingdom and Germany ${ }^{132}$ have remained members, also contributed to converging threat perceptions and persisting security cooperation. The article hence amends Sperling's and Webber's findings on processes of collective securitisation towards Russia within NATO after $2014 .{ }^{133}$ Not merely being an audience and receptor,

\footnotetext{
${ }^{132}$ Sperling and Webber, 'NATO and the Ukraine crisis'.

${ }^{133}$ Ibid.
} 
factors intrinsic to Germany and the United Kingdom contributed to changes in threat perception. Future research could and should delve deeper into these interactions between bottom-up and top-down securitisation.

Fourth, taken together, the findings of this study suggest that the British-German security cooperation towards Russia is likely to continue in its selectively robust form. Recent developments seem to confirm this. In early October 2020, German Foreign Minister Maas condemned recent British legislation that entailed a unilateral break with pre-existing agreements in the course of the Brexit process. ${ }^{134}$ Nonetheless, UK Foreign Minister Dominic Raab strongly supported a statement by Germany and France on 7 October accusing Russia of poisoning Russian oppositionist Navalny and breaching the Chemical Weapons Convention, suggesting that the UK-German Russia policy remains largely insulated from the Brexit process. ${ }^{135}$

Of course, threat perceptions could well diverge in the case of Russia undergoing regime change or dramatically changing its hostile stance towards Ukraine. However, this seems unlikely in the light of the recent solidification of the Russian regime through constitutional reforms. Thus, it also seems unlikely that the United Kingdom and Germany will perceive each other as less reliable or useful allies towards Russia, as the shared sense of a Russian threat had led them to appreciate each other as useful and reliable allies and insulate their policies towards Moscow from the corrosive effects of the Brexit process.

Acknowledgements. The author thanks Fedor Basov for his excellent feedback and support. Special thanks also to Nele M. Ewers-Peters, Joe Ganderson, Jule v. Köhlerwald, Ulrich Krotz, the panelists and attendants of the panel on Emerging Issues in World Politics at the BISA General Conference 2019, the participants of the November 2019 Joint Workshop by the Vrije Universiteit Brussel, the European Initiative for Security Studies (EISS), and the NATO Defence College (NDC) on Intra-Alliance Challenges to NATO's Cohesion and European Security, as well as the anonymous reviewers and editors.

Jonas J. Driedger is a DAAD-AICGS Research Fellow on Transatlantic Security Policy at the American Institute for Contemporary German Studies (Johns Hopkins University) in Washington, DC, where he works on US-German security cooperation towards Russia during the Trump presidency. He is also currently defending his doctoral thesis on the causes of military conflict between major states and their small neighbours at the European University Institute in Florence, Italy. From 2018 to 2019, he was a Visiting Researcher and Alfa Fellow at the Moscow Higher School of Economics. Further research interests include deterrence, military conflict, EU foreign policy, and security policy formation in Europe and Russia.

\footnotetext{
${ }^{134 ،}$ 'Germany says no-deal Brexit would be "irresponsible”, Deutsche Welle (5 October 2020), available at: \{https://www.dw. com/en/germany-says-no-deal-brexit-would-be-irresponsible/a-55158259/\} accessed 10 October 2020.

${ }^{135}$ United Kingdom, 'Russia: UK Responds to French and German Statement on the Poisoning of Alexey Navalny' (7 October 2020), available at: \{https://www.gov.uk/government/news/russia-uk-responds-to-french-and-german-statementon-the-poisoning-of-alexey-navalny\} accessed 10 October 2020.
}

Cite this article: Driedger, J. J. 2021. Bilateral defence and security cooperation despite disintegration: Does the Brexit process divide the United Kingdom and Germany on Russia? European Journal of International Security 6, 86-108. https://doi.org/ 10.1017/eis.2020.18 